\title{
„ODSTĄPCIE, NIE UMARŁa DZIEWECZKA, ALE ŚPI” — ŻYCIE JEST CZEKANIEM NA ŚMIERĆ — z Kaznodziejstwa Fabiana Birkowskiego
}

\begin{abstract}
Albowiem w tym wzdychamy, żądając być przyobleczeni mieszkanim naszym, które jest z nieba; jeśliż jedno obleczonymi, a nie nagimi będziemy nalezieni. Bo i którzy jesteśmy w tym przybytku, wzdychamy obciążeni, przeto że nie żądamy być zwleczeni, ale przyobleczeni: aby pożarte było, co śmiertelne jest, od żywota. A który nas na toż sprawuje, Bóg, który nam dał zadatek Ducha.

Śmiemy tedy zawsze, że pókiśmy w ciele, pielgrzymujemy od Pana (albowiem przez wiarę chodzimy, a nie przez widzenie), a śmiemy i dobrą wolą mamy pielgrzymować raczej od ciała, a przytomnemi być Panu.
\end{abstract}

(2 Kor $\left.5,2-8^{1}\right)$

Dusza (łac. anima; stgr. psyche) była tematem rozważań starożytnych filozofów oraz teologów. Jako pierwszy rozważania na ten temat podjął Sokrates, wcześniej psyche uważane było za przejaw inteligencji, myśli ${ }^{2}$. Sokrates przyjął, że dusza jest właściwa jedynie ludziom i jest przejawem ich człowieczeństwa. Myśl tę kontynuowali dalej Platon oraz Arystoteles. Dla Platona dusza była najdoskonalszym i nieśmiertelnym pierwiastkiem każdego człowieka, który został uwięziony w ciele. Dopiero śmierć ciała pozwala rozpocząć prawdziwe życie $p s y c h e^{3}$. Stagiryta, w przeciwieństwie do swojego poprzednika, uważał, iż dusza nie jest substancją oderwaną od ciała, jest natomiast energią ciała organicznego, która nie może być nieśmiertelna ${ }^{4}$.

W filozofii chrześcijańskiej, w okresie poprzedzającym średniowiecze, rozważania na temat duszy prowadził św. Augustyn. Stworzył on swoją teorię zgodnie z duchem platonizmu i neoplatonizmu, a więc głosił dualizm ciała oraz duszy. Dla św. Augusty-

\footnotetext{
${ }^{*}$ Paulina Poterała - absolwentka polonistyki oraz pedagogiki na Uniwersytecie Łódzkim, doktorantka w Katedrze Literatury Staropolskiej i Nauk Pmocniczych. Jej zainteresowania badawcze oscylują wokół literatury przełomu renesansu i baroku — poezji mieszczańskiej, homiletyki i motywów mitologicznych oraz twórczości kobiet w XIX wieku.

${ }^{1}$ Biblia w przekładzie Jakuba Wujka z 1599 r., oprac. i wstęp ks. J. Frankowski, Warszawa 1999. Fragmenty tego cytatu są zawarte w podsumowaniu kazania Odstapcie, nie umarła dzieweczka, ale śpi Fabiana Birkowskiego.

${ }^{2}$ G. Reale, Historia filozofii starożytnej, t. 1, Lublin 2008, s. 316.

${ }^{3}$ W. Tatarkiewicz, Historia filozofii, t. 1, Warszawa 1970, s. 78.

${ }^{4}$ Tamże, s. $104-105$.
} 
na ciałem było wszystko to, co posiadało trzy wymiary (długość, szerokość i głębokość). Duszę natomiast przedstawił jako „życiodajne tchnienie materii”’ które utożsamił z człowiekiem — duszą rozumną, posługującą się ciałem wyłącznie z konieczności. W pierwszym okresie swej działalności św. Augustyn uważał związek duszy i ciała za nienaturalny, w późniejszym czasie, podążając za zmianami w filozofii chrześcijańskiej, zmienił pogląd, twierdząc, że ciało utraciło swą doskonałość przez grzech pierworodny ${ }^{6}$.

Św. Tomasz z Akwinu, podążając za myślą Arystotelesa, twierdził, że ciało wraz z duszą należy do natury człowieka, a więc stanął na stanowisku psychofizycznej jedności człowieka ${ }^{7}$.

Teorie świętych Augustyna oraz Tomasza były podtrzymywane w naukach kościelnych. Tomizm stał się oficjalną nauką zakonu dominikanów ${ }^{8}$ oraz jezuitów ${ }^{9}$, zaś Stolica Apostolska uznała myśl św. Tomasza za oficjalną naukę Kościoła ${ }^{10}$. Poglądy św. Augustyna powrócily w XVII wieku, po okresie reformacji ${ }^{11}$.

Jednym ze świadectw odwołania się do augustynizmu, szczególnie do teorii dualizmu duszy i ciała, jest kazanie Odstapcie, nie umarła dzieweczka, ale śp $i^{12}$ dominikanina Fabiana Birkowskiego opublikowane na początku XVII wieku. W Sumariuszu kazań niedzielnych jest to kazanie drugie na XXIII niedzielę po Świątkach opisane w następujący sposób: „O pragnieniu śmierci, które święci mieli, i dlaczego mają”. W oracji tej autor jednoznacznie podzielił człowieka na dwie części — ciało (związane z życiem ziemskim, grzechem i fizjologia) oraz duszę (połączoną z Bogiem). Dualizm ciała i duszy wywołuje w każdym wierzącym człowieku pragnienie śmierci, a więc ucieczki od fizycznej formy życia. Najlepszym sposobem uwolnienia jest śmierć w młodym wieku, ponieważ dusza jest krótko połączona z ciałem. Natomiast obumarcie ciała na starość, długie życie, powoduje cierpienie najdoskonalszej części człowieka, jaką jest dusza. Zatem śmierć była dla kaznodziei czymś, czego ludzie powinni pragnąć od samego początku życia.

Kazanie Birkowskiego pochodzi ze zbioru Kazania na niedziele $i$ święta dorocz$n e^{13}$ wydanego w całości dwukrotnie w 1620 roku oraz wznowionego w latach 1623

${ }^{5}$ A. Kasia, Św. Augustyn, Warszawa 1960, seria „Myśli i Ludzie. Filozofia starożytna i średniowieczna”, t. 1 , s. 44 .

${ }^{6}$ Tamże, s. 44-49.

${ }^{7}$ W. Tatarkiewicz, dz. cyt., s. 266.

${ }^{8}$ Zakon dominikański uznał na kapitułach generalnych w latach 1278-1313 naukę św. Tomasza z Akwinu za obowiązujące nauczanie zakonu dominikańskiego.

${ }^{9}$ Zakon jezuitów uznał naukę św. Tomasza z Akwinu za swoją oficjalną naukę w XVI wieku.

${ }^{10}$ W. Tatarkiewicz, dz. cyt., s. 269.

${ }^{11}$ Tamże, s. 191.

${ }^{12}$ F. Birkowski, Kazania na niedziele i święta doroczne, Kraków 1628.

${ }^{13}$ Kazania na niedziele $i$ święta doroczne wydane były dwukrotnie 1620 i 1628 roku w oficynie dziedziców A. Piotrkowczyka. Zostały zadedykowane Władysławowi IV. Program kazań Birkowskiego nie był tylko wyrazem poglądów autora, ale również całego zakonu dominikanów. Świadczy o tym aprobacja 
i 1628. Zostało napisane na dwudziestą trzecią niedzielę po Świątkach ${ }^{14}$. Rozpoczyna je perykopa z Ewangelii według św. Mateusza, która składa się z dwóch części: pierwsza dotyczy kobiety cierpiącej na krwotok, druga córki Jaira ${ }^{15}$.

Sama historia córki Jaira została przez kaznodzieję krótko omówiona — nie stała się ona głównym tematem kazania, lecz przyczynkiem do rozważań o wartości i sensie życia oraz śmierci człowieka. Istotnym zdaje się fakt, iż dominikanin, wykorzystując perykopę, pominął w kazaniu informację na temat wskrzeszenia zmarłej dziewczynki, dzięki temu mógł dowodzić tezy odbiegającej od istoty przekazu ewangelicznego. Dla Birkowskiego żywot ziemski na każdym jego etapie był wyłącznie cierpieniem, strachem oraz czasem, w którym człowiek doświadczał ciągłych upokorzeń. Tym samym kaznodzieja odwołał się do jednej z ksiąg dydaktycznych Starego Testamentu — Księgi Koheleta. Śmierć jest natomiast łaską daną od Boga, wyzwoleniem od mąk, pragnieniem wszystkich ludzi wierzących, ponieważ prowadzi do prawdziwego, wyczekiwanego życia u boku Stwórcy.

Kazanie swoje Birkowski podzielił na trzy części. W pierwszej bezpośrednio odwołał się do treści perykopy; w drugiej, najdłuższej, omówił życie ziemskie; w trzeciej przedstawił wizję raju.

Początek nauki, który miał na celu objaśnienie fragmentu Pisma Świętego, skoncentrował się na kwestii opłakiwania zmarłych. Birkowski jednoznacznie stwierdził, że było to niewłaściwe zachowanie, niezależnie od tego czy umierała jedna osoba, czy więcej: „Ten który nad grobem Łazarzowym i nad miastem jerozolimskim płakał, zakazuje płakać i lamentów stroić nad zmarłą panienką [...]"16.

Czasownik „zakazuje” nie jest tu przypadkowy, sugerował naganność, a nawet grzeszność. Zatem lament po zmarłym uważał kaznodzieja za wystąpienie przeciwko nakazom Bożym — zanegowanie ich. Birkowski postawił tezę, parafrazując i omawiając słowa Chrystusa z perykopy:

Zakazał płakać Chrystus w tym domu, albowiem śmierć dwunastoletniej panny niegodna była takich lamentów. Umarła w niewinności; usnęła raczej, nie umarła, jako sam Chrystus mówi: o cóż płakać? ${ }^{17}$

cenzorska dołączona do wydania z 1620. Teksty były sprawdzane przez trzech dominikańskich teologów. (J. Śniegocki, Z problemów kaznodziejstwa Fabiana Birkowskiego (1566-1636), „Studia Płockie”, 1977, t. V, s. 6.)

${ }^{14}$ Jest to XXIII niedziela zwykła po dniu Zesłania Ducha Świętego (święto ruchome, które przypada 49 dni po Niedzieli Zmartwychwstania Pańskiego), potocznie zwanym Zielonymi Świątkami. Zwyczajowo w tym czasie, czyta się fragmenty Ewangelii według św. Mateusza. Zob. Encyklopedia Kościelna podtug teologicznej encyklopedii Wetzera $i$ Weltego z licznemi jej dopetnieniami przy wspótudziale wielu duchownych i świeckich, wyd. M. Nowodworski, Warszawa 1899, t. 23, s. 447-451 (hasło: rok kościelny).

${ }^{15}$ Birkowski krótko odwołuje się, we wtórym kazaniu, do historii kobiety cierpiącej na krwotok na stronie 814 .

${ }^{16}$ Wszystkie cytaty z kazania Odstapcie, nie umarła dzieweczka, ale śpi za F. Birkowski, Kazania na niedziele i święta doroczne, Kraków 1628, s. 810-817.

${ }^{17}$ Tamże, s. 810. 
Śmierć córki Jaira przyrównana została przez Chrystusa do zaśnięcia, któremu towarzyszyły spokój i łagodność, a nie strach i cierpienie. Co więcej, sen jest naturalnym, fizjologicznym stanem, z którego człowiek zawsze się wybudza. Dziewczynka zasnęła dla ludzi na zawsze, lecz wybudzi się w niebie dla Boga. Dostąpi ona łaski życia wiecznego, dzięki śmierci w niewinności. Niewinności - własności przypisywanej jedynie dzieciom, które podczas krótkiego życia, nie zbrukały się jeszcze grzechem. Zatem, jak stwierdził kaznodzieja, nie można opłakiwać śmierci dzieci, gdyż jest ona dla nich darem i wyzwoleniem od niegodziwości oraz zła ludzkiego świata, a także ucieczką w dobro — świat Boga. Birkowski wyróżnił tym samym dwa światy. Pierwszy był przeznaczony dla ludzi godnych łaski Boga, drugi dla ludzi grzesznych. Do pierwszego przynależała dusza człowieka, a do drugiego jego ciało. Podobny podział znajdziemy w heteronomicznej etyce świętego Augustyna, który wyróżnił „państwo Boże” (civitas Dei) i „państwo ziemskie" (civitas terrena). W civitas Dei znajdować się miały wyłącznie stworzenia podążające za Bogiem, w civitas terrena stworzenia sprzeciwiające się Bogu ${ }^{18}$. Św. Augustyn pisał: „Ziemskie — w sobie chwały szuka, niebieskie — w Panu. Bo ziemskie szuka jej u ludzi; dla niebieskiego Bóg, sumienia świadek jest chwałą najwyższą"19.

Birkowski opisał civitas Dei, a więc świat, w którym po śmierci ciała zamieszkała córka Jaira.

Chwyćmy się dnia onego [...], który nas stąd wyrwie [...] do Raju wniesie i do królestwa niebieskiego. Wielka liczba miłych nas tam czeka, rodziców, braci, synów [...]. Jakie wesele będzie, gdy się przywitamy i obłapimy z nimi i nasze, i ich? Jaka w królestwach tamtych górnych rozkosz, ponieważ nie masz tam żadnego strachu śmierci, a żywot tam jest wieczny, szczęście nieustające ${ }^{20}$ ?

Świat Boży — raj jest krainą wiecznej szczęśliwości, pozbawionej strachu i bólu, zatem lamentować nie można również nad dorosłymi osobami wierzącymi, które żyły według nakazów Bożych, bowiem ich dusza zostanie „zaniesiona na łono Abrahamowe [...] w dobre ręce poszła" 21 .

Jedynie ludzie grzeszni, zdaniem Birkowskiego, sprzeciwiający się woli Pańskiej powinni płakać nad swoim losem: „[...] płakał Absalona, ten abowiem umarł wiecznie, w grzechu śmiertelnym, zabity na wojnie, którą przeciwko ojcu podniósł"22.

Absalom — syna Dawida — zgrzeszył, występując przeciwko ojcu. Umarł bolesną śmiercią na wojnie. Został ugodzony trzema sztyletami przez Joaba, a następnie skatowany przez jego dziewięciu giermków ${ }^{23}$. Za swój uczynek zapłacił nie tylko okrutną

\footnotetext{
${ }^{18}$ W. Tatarkiewicz, $d z$. cyt., s. 189.

${ }^{19}$ Św. Augustyn, Państwo Boże, przekł. W. Kłubicki, t. 14, s. 28. Za: A. Kasia, Św. Augustyn, [w:] Seria Myśli i Ludzie. Filozofia starożytna i średniowieczna, red. J. Legowicz, Warszawa 1960, t. 1, s. 133.

${ }^{20}$ F. Birkowski, dz. cyt., s. 815.

${ }^{21}$ Tamże, s. 810.

${ }^{22}$ Tamże, s. 810.

${ }^{23}$ Pismo Święte Starego i Nowego Testamentu, oprac. Zespół biblistów polskich z inicjatywy benedyktynów tynieckich, wyd. 3 popr., Poznań-Warszawa 1980 (2 Sm 18, 1-18).
} 
śmiercią, ale przede wszystkim wiecznym potępieniem. Jest to najwyższa kara dla osoby wierzącej, dlatego Absalom, według dominikanina, słusznie płakał nad swoim losem. Jednak nie zasłużył on na litość i współczucie ludzi, ponieważ sam dokonał wyboru.

Zestawienie przez kaznodzieję opowieści o córce Jaira, z opowieścią o Absalomie, a więc bezbolesnego spokojnego snu i życia wiecznego, z bolesną śmiercią poprzez zabicie i wieczne potępienie, podkreślić miało kontrast między losem, jaki czekał osobę niewinną a losem grzesznika.

Pierwszą część kazania Birkowski podsumował następującym zdaniem: „Iż tedy ta panienka w łasce Bożej umarła była, [...] jest czego pragnąć umrzeć tak, jako ta panna umarła, której śmierć snem Pan zowie [...]"24.

Kaznodzieja dowodził, że takiej śmierci powinien pragnąć każdy człowiek, gdyż życie na ziemi jest więzieniem dla jego duszy, która chce uwolnić się od ciała i odejść do Boga. Jest łaską daną od Boga. Birkowski przyrównał więź między duszą a ciałem do obcowania człowieka z rozkładającymi się zwłokami. Odwołał się do jednej z najokrutniejszych tortur, jaką stosował wobec ludzi mitologiczny król Etrusków - Mezentius: „[...] z trupami wiązał, oczy z oczyma, usta z ustami, ręce z rękami, aby od smrodu ich męczeni byli i zabijani, pragnęli jako naprędzej od tych węzłów być wolni [...]"25.

Cierpienia przyrównanego do tortur stosowanych przez króla Etrusków były świadome jedynie osoby wierzące, takie, które swoim życiem zasłużyły na łaskę wieczności. Pragnęly one złączenia z Bogiem, aby rozpocząć prawdziwe życie, gdyż to ziemskie było wyłącznie oczekiwaniem na śmierć. Ciało ludzkie przyrównane zostało do zwłok, ponieważ z czasem zaczynało się starzeć — rozkładać. Im człowiek dłużej żył, tym dotkliwsza była kara, a więc kaznodzieja ponownie stwierdził, iż najlepiej jest umrzeć w młodym wieku.

Słowa o przewadze duszy nad ciałem stanowiły nawiązanie do poglądów św. Augustyna, który uważał, iż najdoskonalszą formą człowieka jest niezniszczalna dusza - związana z Bogiem i dobrem. Ciało natomiast było odpowiedzialne za funkcje biologiczne naznaczone złem, ulegało zniszczeniu oraz było źródłem potępianych pragnieñ $^{26}$. W pierwszym okresie swojej twórczości św. Augustyn uważał za Platonem, że dusza jest uwięziona w ciele, zatem pragnie wyswobodzić się i położyć kres temu nienaturalnemu związkowi ${ }^{27}$. Tę samą koncepcję przedstawił w swoim kazaniu Birkowski, który udowadniał, iż życie było od samego jego początku cierpieniem dla boskiej cząstki człowieka, jaką jest dusza.

Birkowski analizował w kazaniu kolejne etapy życia człowieka, od poczęcia po starość, udowadniając, że każdy z nich jest dotkliwy, ponieważ jest związany z cielesnością. Swoje rozważania rozpoczął nawiązując do momentu poczęcia, który uznał za przejaw żądzy człowieka. Już samo powstanie ludzkiego życia było naznaczone grzechem. Następnie kaznodzieja opisał czas spędzony w łonie matki i poród:

\footnotetext{
${ }^{24}$ F. Birkowski, dz. cyt., s. 810.

${ }^{25}$ Tamże, s. 810.

${ }^{26}$ W. Tatarkiewicz, dz. cyt., s. 186.

${ }^{27}$ A. Kasia, dz. cyt., s. 47.
} 
[...] więźniem będzie niemal dziewięć miesięcy w żywocie macierzyńskim, karmi się krwią miesięczną obrzydliwą. Wychodzi potym na świat odziane w krwawą sukmanę nędzne, ubogie, narzekające na stan swój z wielkim niebezpieczeństwem matki, z bólem czołga się jako robak jaki [...] $]^{28}$.

Kaznodzieja zbudował sugestywny obraz, odwołując się do płodowego rozwoju człowieka oraz fizjologii porodu. Birkowski, który zapewne opierał swój wywód na ówczesnej wiedzy na temat odżywiania płodu, uważał, iż nienarodzone dziecko pożywiało się krwią menstruacyjną matki. Poród przedstawił jako zagrożenie dla życia kobiety, która mogła umrzeć wydając na świat dziecko. Ponadto człowiek nie rodził się czysty, lecz ubrudzony krwią. W ten symboliczny sposób Birkowski sugerował, że ludzie, już od narodzin, naznaczeni byli grzechem. Zarówno obraz ciąży, jak i porodu ma podkreślić, jak bardzo bolesny i niepewny jest początek życia każdego człowieka.

W pierwszych latach swego życia dziecko było bezbronne, słabe uzależnione od pomocy innych osób. Nie było w stanie żyć bez wsparcia, troski, etc. Co więcej, nie chodziło jak dorosły człowiek, ale ,jak bydle na czterech nogach”. Nie potrafiło mówić — „bełkotało”. Określenia te porównały, a nawet zrównały człowieka, w jego pierwszych latach życia ze zwierzęciem — istotą niższego gatunku niż ludzki.

Kaznodzieja podkreślił, że nie tylko los dziecka był niepewny. Według niego, człowiek, w niemalże każdym wieku, nie czuł się bezpieczny i szczęśliwy, ponieważ życie ludzkie to wyłącznie cierpienie, choroba i strach:

Otoczą go zatym tysiącem niebezpieczeństwa, frasunków bez miary, nigdy zdrowia swego nie jest bezpieczen, ani gdy dzieciną, ani gdy młodzieńcem bywa. Dopieroż szczęście nad nim sztuki swe wyprawia, gdy do męstwa przydzie, rzadki do starości, ale i tam przyszedszy, nic już koniec, sama starość chorobą ${ }^{29}$.

Jedynie dojrzały człowiek może zaznać odrobiny szczęścia, jednak ten etap szybko zamienia się w starość — czas chorób, który prowadzi do końca życia.

Birkowski zrównał dzieci, ludzi młodych i dojrzałych oraz starców, ponieważ dla nich wszystkich śmierć jest wyzwoleniem od cierpienia oraz strachu. Ludzie, zdaniem autora kazania, bez względu na wiek, powinni chcieć uwolnienia duszy od ciała. Kaznodzieja nie widział sensu egzystencji na żadnym etapie życia człowieka — zarówno młodość, jak i starość powodowały wyłącznie negatywne uczucia. Jednak podkreślił, że z biegiem lat poczucie bólu, nieszczęścia stawało się coraz bardziej dotkliwe.

$\mathrm{Z}$ wiekiem przybywa pokus, jakim ulegało ciało ludzkie. W życiu ziemskim dusza podlegała ciału, nie była w stanie obronić się przed grzechem, a nawet go rozpoznać, a więc przegrywa z nim. Zatem, jak stwierdził kaznodzieja, człowiek ulegał kłamstwu, jakim jest pożądanie, bogactwo czy wysoki urząd. Według Birkowskiego, każdy, kto choć po części zrozumie, jak marne oraz występne jest jego życie, zapragnie umrzeć, by nie obrażać Boga swoimi grzechami. Zapragnie porzucić fałszywe dobra i oddać

\footnotetext{
${ }^{28}$ F. Birkowski, dz. cyt., s. 812.

${ }^{29}$ Tamże, s. 812.
} 
się w opiekę Stwórcy. Kaznodzieja, by potwierdzić swe przekonanie przywołał słowa jednego z anglikańskich męczenników, być może Edmunda Campiona:

Jeśli prawdziwie miłujesz Boga, zaprawdę (mówi), [...] niczego więcej pragnąć nie będziesz jako lekarstwa jakiego, przez które mógłbyś być upewniony, iż Pana Boga nigdy nie obrazisz, co iż w tym żywocie zachować się nie może [...], ustawicznie wołać będziesz z Psalmistą: „[...] pragnę być rozwiązany” [...] $]^{30}$.

Śmierć jest lekarstwem, tym samym życie staje się chorobą, która nie tylko powoduje cierpienie człowieka, ale też obraża samego Boga. Żaden człowiek nie jest wolny od grzechu, zatem każde życie należy nazwać chorobą — również życie Birkowskiego, który pisał o sobie:

Co, jeśli Bóg, który wie nędze te, chce mi żywota przedłużyć i dłużej mię więzić w tym padole ucisków? [...] pokornie proszę, aby od tej godziny, w którą to piszę, już się poczęło i trwało aż do kresu żywota mojego. Dopuść Panie, abym dla ciebie był męczony, rąbany, biczowany, bity, niczego się nie zbraniam $[\ldots]^{31}$.

Birkowski pragnął uwolnić się od życia ziemskiego. Pokornie prosił Boga, by ten zlitował się nad nim i zakończył jego cierpienia. Całkowicie zdał się na Boga — przyjmował każdą formę śmierci, nawet męczeńską, gdyż będzie ona mniej bolesna, niż trwanie w więzieniu, jakim jest grzeszne, słabe ciało. Kaznodzieja nie miał wątpliwości, iż jego życie jest marnością, jest nieustannym czekaniem na śmierć, która doprowadzi jego duszę do Boga, a więc nada sens jego istnieniu: „wszystko mogę w tobie, a bez ciebie nic" ${ }^{32}$. Słowa te są uniwersalne, może je wypowiedzieć każdy „święty męczennik”.

Zatem jedynym ratunkiem przed cierpieniem, upokorzeniem i grzechem jest dla człowieka śmierć: „Rozwiązuje to wszystko śmierć, i czyni nas bez cierpienia, bez grzechu, niebiesczykami boskimi”"33.

Birkowski zastanawiał się nad tym, czy życie ziemskie powinno być nazywane właśnie życiem. Dla niego czas połączenia duszy i ciała — pełen grzechu, bólu i upokorzeń - jest raczej śmiercią, ta nazwa wydała mu się odpowiedniejsza. Na kanwie tego przekonania oparł całe kazanie, udowadniając, iż bez względu na wiek, życie ludzkie pozbawione jest jakiejkolwiek wartości. Dopiero moment śmierci i obcowanie duszy z Bogiem nadaje ludzkiemu istnieniu znaczenie.

Tekst Birkowskiego miał na celu poruszyć wyobraźnię, wywołać głównie negatywne emocje — strach, poczucie beznadziei — dzięki czemu zostawał w pamięci słuchaczy lub czytelników i stawał się dla nich przestrogą oraz drogowskazem. Kaznodzieja, odwołując się do przykładów oraz własnego pragnienia śmierci, chciał przede wszystkim oddziaływać na wolę i emocje odbiorców, a więc skoncentrował się na funkcji movere.

\footnotetext{
${ }^{30}$ Tamże, s. 812-813.

${ }^{31}$ Tamże, s. 813.

32 Tamże, s. 813.

${ }^{33}$ Tamże, s. 814.
} 
Janusz Śniegocki stwierdził, iż dominacja movere w kazaniach homilijnych pokazała, że Birkowski oddalał się od renesansowego wzorca sztuki kaznodziejskiej, w której dominowała funkcja docere. Tym samym inicjował nowe tendencje, które rozwinęły się w dojrzałym baroku ${ }^{34}$. Szukanie ekspresji wyrazu, szczegółowe obmyślanie konstrukcji kazania jest znamienną cechą twórczości Birkowskiego, zaczerpniętej po części z nowego wzoru retoryki Lipsiusa ${ }^{35}$.

Analiza kazania pokazała, że poglądy, teorie św. Augustyna były kultywowane i przekazywane w siedemnastowiecznych naukach Kościoła, a więc traktowane jako aktualne. Kaznodzieja przyjął, w duchu myśli augustiańskiej, że ciało jest śmiertelną częścią człowieka, która odpowiada za grzech i fizjologię, natomiast duszę potraktował, jako najdoskonalszą cząstkę związaną z Bogiem. Nienaturalny związek ciała i duszy przedstawił jako dotkliwy dla ludzi, ponieważ przynosi, podczas życia w civitas terrena jedynie ból i udrękę. Ten dualizm sprawia, że człowiek pragnie odejścia do civitas Dei, a więc jak najszybszej śmierci. Najszybszej, czyli takiej, która nastąpi jeszcze w dzieciństwie, ponieważ kolejne etapy życia, w szczególności lata młodzieńcze i starość są, według Birkowskiego, czasem niepokoju, grzechu oraz cierpienia. Im dłużej dusza połączona jest z ciałem, tym dotkliwsza staje się ludzka egzystencja.

Odwołanie się do myśli św. Augustyna oraz snucie pesymistycznej wizji na temat sensu życia człowieka służyło nakłonieniu, a nawet zmuszeniu, ludzi do prawidłowego postępowania, które zapewni szczęśliwe życie duszy u boku Boga. Myśl przewodnia kazania oparta została zatem nie tylko na dualizmie człowieka (dusza i ciało), ale również na dualizmie życia tego prawdziwego i szczęśliwego (civitas Dei) oraz złudnego i nieszczęśliwego (civitas terrena).

Paulina Poterała

\section{„ODSTĄPCIE, NIE UMAREA DZIEWECZKA, ALE ŚPI” — LIFE IS A WAIT FOR DEATH — FROM THE HOMILETICS OF FABIAN BIRKOWSKI}

Summary

The aim of this paper is to discuss the influence of the St Augustine thoughts on the sermon Go away, the girl is not dead, but asleep from The Sermons on Sundays Annual Celebrations. The article focuses on the issue of human dualism (division into soul and body) as well as life dualism (civitas Dei and civitas terrena).

Słowa kluczowe: augustynizm, kaznodziejstwo, Fabian Birkowski

Keywords: Augustinism, homiletics, Fabian Birkowski

\footnotetext{
${ }^{34}$ J. Śniegocki, op. cit., s. 4.

${ }^{35}$ Fabian Birkowski korespondował z Lipsiusem Justusem (właśc. Joost Lips). Zob. J. Dąbkowska-Kujko, Justus Lipsjusz i początki europejskiego neostoicyzmu w zwierciadle polskiej prozy, [w:] Humanitas (paideia). Antropologia humanistyczna w kontekstach filozoficznych, red. A. Nowicka-Jeżowa, t. 1, Warszawa 2009/2010, s. 203-228.
} 